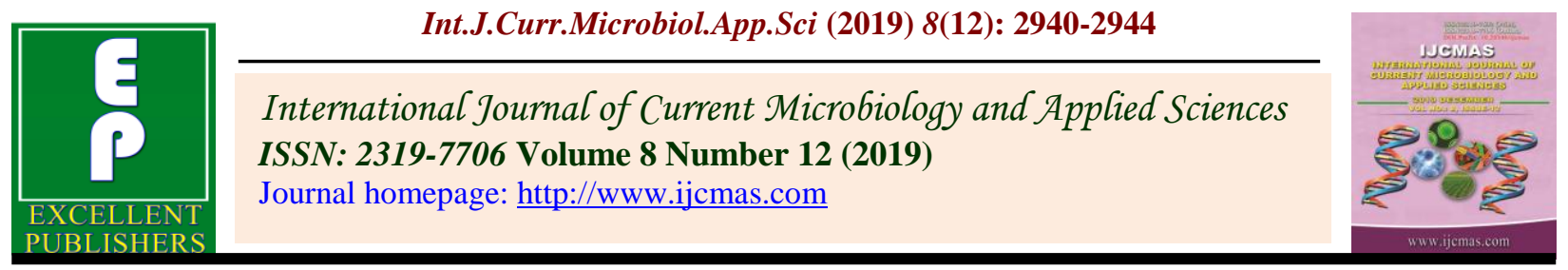

Original Research Article

https://doi.org/10.20546/ijcmas.2019.812.341

\title{
Effect of Levels of Sulphur and Plant Growth Regulators on Growth, Yield and Oil percentage of Summer Groundnut (Arachis hypogaea L.)
}

\author{
B. Rama Krishna and Rajesh Singh* \\ Department of Agronomy, SHUATS, Prayagraj, India \\ *Corresponding author
}

\begin{tabular}{|l|}
\hline Ke y w o r d s \\
$\begin{array}{l}\text { Groundnut, Zaid, } \\
\text { Sulphur, Yield } \\
\text { attributes, Gypsum, } \\
\text { Kernel weight, Oil } \\
\text { content }\end{array}$ \\
\hline Article Info \\
\hline $\begin{array}{l}\text { Accepted: } \\
\text { 20 November } 2019 \\
\text { Available Online: } \\
10 \text { December } 2019\end{array}$ \\
\hline
\end{tabular}

A B S T R A C T

The experiment was conducted during the Zaid season 2018 at Prayagraj to study the Sulphur and Plant Growth Regulators on Growth, Yield and Oil percentage of Summer Groundnut (Arachis hypogaea L.). The experiment comprised of 2 factors and 13 treatments viz. Sulphur $\left(30,40,50 \mathrm{~kg} \mathrm{ha}^{-1}\right)$ and Plant growth regulators (NAA $50 \mathrm{ppm}$ (at 20 DAS alone \& at 20, 40 DAS), $\mathrm{GA}_{3} 30 \mathrm{ppm}$ (at 20 DAS alone \& at 20, 40 DAS)) and control. Sulphur and Plant growth regulators application significantly influenced the growth, yield attributing characters, yield and oil content over control. Addition of sulphur at $40 \mathrm{~kg} \mathrm{ha}^{-1}$ along with foliar application of $50 \mathrm{ppm}$ NAA twice at 20 DAS and 40 DAS recorded highest plant height (38.47 $\mathrm{cm})$, plant dry weight $(82.15 \mathrm{~g})$, pod yield $\left(1.97 \mathrm{t} \mathrm{ha}^{-1}\right)$ and oil content $(47.23 \%)$ sulphur at $50 \mathrm{~kg} \mathrm{ha}^{-1}$ along with foliar application of $\mathrm{GA}_{3} 30 \mathrm{ppm}$ at 20 \& 40 DAS was seen in the kernels.

\section{Introduction}

Groundnut is annually grown on about $24 \mathrm{~m}$ ha of land in about 120 countries under different agro-climatic zones between $400 \mathrm{~S}$ and $400 \mathrm{~N}$ (DGR, 2013). It occupies premier position with regards to area and production in India. India accounts about 20 per cent area and less than 10 per cent production of oilseed of the world. Whereas, groundnut accounts for 40 per cent of the area and 30 per cent of the production of total oilseeds grown in the country (Anonymous, 2009-10). Currently, six states viz: Gujarat, Andhra Pradesh, Karnataka, Tamil Nadu, Maharashtra and Rajasthan account for more than 90 per cent of the total groundnut area and 89.3 per cent of total production. Gujarat ranks first in area and production of this crop. In the recent years, the area under summer groundnut has increased due to assured and higher profit and productivity as it is grown under assured irrigation facility and lesser incidence of a biotic and abiotic stresses on crop as 
compared to rainy season (Rana et al., 2014). Despite of being such an important oilseed crop, the average productivity in the state is lower than nation level as well as its production potential. Hence, our efforts should be aimed to remove the constraints responsible for its poor productivity. Sulphur is also known to promote nodulation in legumes there by $\mathrm{N}$ fixation and associated with the crops of spurious nutrition and market quality. Its application increases drought and cold tolerance in plant by process of disulphide linkage. Gypsum is another material huge deposits of which are found in the state of UP and being excavated at large scale. It has been the endeavour of crop physiologists to influence crop growth and production by the exogenous application of the growth regulators. Spraying of NAA during early crop growth stage, especially before flower initiation have been found to result in a higher fertility of flower, early fruit set and increasing the number of filled pods per plant (Gopalakrishnan and Srinivasan, 1975: Valliappan et al., 1985 and Rao, 1997). Gibberellic acid has been used as a growth regulator to increase yields in different crops like paddy (Sinha, 1969).

\section{Materials and Methods}

The experiment was conducted during the Zaid season of 2018 at Crop Research Farm, Department of Agronomy, Naini Agricultural Institute, Sam Higginbottom University of Agriculture, Technology \& Sciences, Prayagraj (U.P.) India. Soil was sandy clay loam having $\mathrm{pH} 7.2$, organic carbon around $0.42 \%$, available nitrogen at $245 \mathrm{~kg} \mathrm{ha}^{-1}$, available $\mathrm{P}_{2} \mathrm{O}_{5}$ at $14.8 \mathrm{~kg} \mathrm{ha}^{-1}$ and $\mathrm{K}_{2} \mathrm{O}$ at $343.2 \mathrm{~kg} \mathrm{ha}^{-1}$. The experiment was laid out in Randomized Block Design consisting of 13 treatment combinations each replicated three times. Different levels of Sulphur (30, 40 and $50 \mathrm{~kg} \mathrm{ha}^{-1}$ ) and different Plant growth regulators (NAA $50 \mathrm{ppm}$ at 20 DAS, NAA 50 ppm twice at $20 \& 40 \mathrm{DAS}, \mathrm{GA}_{3} 30 \mathrm{ppm}$ at 20 $\mathrm{DAS}, \mathrm{GA}_{3} 30 \mathrm{ppm}$ twice at $20 \& 40$ DAS).Treatments were randomly arranged in each replication. Data on different growth parameters, yield attributes and yield were recorded from randomly selected ten tagged plants from net plot. The percentage of oil content in seed was determined by solvent extraction method in Soxhlet apparatus with petroleum ether as solvent (AOAC, 1980).

\section{Results and Discussion}

Application of Sulphur at the rate of $40 \mathrm{~kg} \mathrm{ha}^{-1}$ along with foliar application of NAA at the rate of $50 \mathrm{ppm} \mathrm{ha}^{-1}$ at $20 \& 40$ DAS gives highest pant height $(38.47 \mathrm{~cm})$. The results are confirmed by Singh et al., (2008), Kalaiyarasan et al., (2003) that plant height increases with increased application of sulphur and $\mathrm{GA}_{3}$ and NAA. Highest plant dry weight $(82.15 \mathrm{~g})$ was found in which Sulphur was applied at the rate of $40 \mathrm{~kg} \mathrm{ha}^{-1}$ along with foliar application of NAA at the rate of 50 ppm $\mathrm{ha}^{-1}$ at $20 \& 40$ DAS. A significant increase in plant dry matter at different stages of growth due to increase in Sulphur levels $\mathrm{GA}_{3}$ and NAA It engages in activation of a number of enzymes participating in dark reaction of photosynthesis via improvement in general and their activation at cellular level by promoting greater photosynthesis and meristematic activity seemed to have stimulated vegetative growth of crops in terms of dry matter accumulation. Maximum Pod yield $\left(1.97 \mathrm{t} \mathrm{ha}^{-1}\right)$ was recorded in Treatment Sulphur was applied at the rate of $40 \mathrm{~kg} \mathrm{ha}^{-1}$ along with foliar application of NAA at the rate of $50 \mathrm{ppm} \mathrm{ha}^{-1}$ at $20 \& 40$ DAS. Supply of sulphur and $\mathrm{GA}_{3}$ and NAA in adequate amount also helps in the development of floral primordial i.e. reproductive parts, which results in the development of pods and kernels in plants. Similar findings have also been reported earlier by Gupta and Singh (1982) and Patel et al., (2009). 
Table.1. Plant growth, Yield \& Oil Content of Groundnut as effected by different treatments at Harvest

\begin{tabular}{|c|c|c|c|c|c|}
\hline S. No. & Treatments & $\begin{array}{c}\text { Plant } \\
\text { height } \\
(\mathrm{cm})\end{array}$ & $\begin{array}{c}\text { Dry } \\
\text { weight (g) }\end{array}$ & $\begin{array}{c}\text { Pod } \\
\text { yield }(t \\
\left.\text { ha }^{-1}\right)\end{array}$ & $\begin{array}{c}\text { Oil } \\
\text { content } \\
(\%)\end{array}$ \\
\hline 1 & $30 \mathrm{~kg} \mathrm{ha}^{-1} \mathrm{~S} \&$ NAA $50 \mathrm{ppm}$ at 20 DAS & 33.80 & 70.40 & 1.80 & 43.20 \\
\hline 2 & $30 \mathrm{~kg} \mathrm{ha}^{-1} \mathrm{~S} \& \mathrm{NAA} 50 \mathrm{ppm}$ at $20 \&$ 40DAS & 33.40 & 71.50 & 1.79 & 42.57 \\
\hline 3 & $30 \mathrm{~kg} \mathrm{ha}^{-1} \mathrm{~S} \& \mathrm{GA}_{3} 30 \mathrm{ppm}$ at $20 \mathrm{DAS}$ & 33.21 & 71.59 & 1.79 & 42.70 \\
\hline 4 & $30 \mathrm{~kg} \mathrm{ha}^{-1} \mathrm{~S} \& \mathrm{GA}_{3} 30 \mathrm{ppm}$ at20 \& 40 DAS & 36.13 & 73.80 & 1.81 & 45.87 \\
\hline 5 & $40 \mathrm{~kg} \mathrm{ha}^{-1} \mathrm{~S} \&$ NAA $50 \mathrm{ppm}$ at 20 DAS & 34.25 & 71.53 & 1.82 & 42.70 \\
\hline 6 & $40 \mathrm{~kg} \mathrm{ha}^{-1} \mathrm{~S} \&$ NAA $50 \mathrm{ppm}$ at $20 \& 40 \mathrm{DAS}$ & 38.47 & 82.15 & 1.97 & 46.80 \\
\hline 7 & $40 \mathrm{~kg} \mathrm{ha}^{-1} \mathrm{~S} \& \mathrm{GA}_{3} 30 \mathrm{ppm}$ at $20 \mathrm{DAS}$ & 36.13 & 77.83 & 1.81 & 45.97 \\
\hline 8 & $40 \mathrm{~kg} \mathrm{ha}^{-1} \mathrm{~S} \& \mathrm{GA}_{3} 30 \mathrm{ppm}$ at $20 \& 40 \mathrm{DAS}$ & 38.02 & 81.67 & 1.93 & 46.21 \\
\hline 9 & $50 \mathrm{~kg} \mathrm{ha}^{-1} \mathrm{~S} \&$ NAA $50 \mathrm{ppm}$ at 20 DAS & 36.40 & 78.26 & 1.89 & 43.67 \\
\hline 10 & $50 \mathrm{~kg} \mathrm{ha}^{-1} \mathrm{~S} \&$ NAA $50 \mathrm{ppm}$ at $20 \& 40 \mathrm{DAS}$ & 37.60 & 80.95 & 1.90 & 46.80 \\
\hline 11 & $50 \mathrm{~kg} \mathrm{ha}^{-1} \mathrm{~S} \& \mathrm{GA}_{3} 30 \mathrm{ppm}$ at $20 \mathrm{DAS}$ & 35.83 & 79.53 & 1.90 & 46.10 \\
\hline 12 & $50 \mathrm{~kg} \mathrm{ha}^{-1} \mathrm{~S} \& \mathrm{GA}_{3} 30 \mathrm{ppm}$ at $20 \& 40 \mathrm{DAS}$ & 37.10 & 80.67 & 1.92 & 47.23 \\
\hline \multirow[t]{3}{*}{13} & Control & 33.75 & 71.31 & 1.75 & 44.00 \\
\hline & SEm \pm & 0.91 & 2.51 & 0.03 & 0.55 \\
\hline & $\mathrm{CD}(\mathrm{P}=0.05)$ & 2.67 & 9.41 & 0.09 & 1.61 \\
\hline
\end{tabular}


Maximum oil content (47.23\%) was recorded in which sulphur was applied at the rate of 50 $\mathrm{kg} \mathrm{ha}^{-1}$ along with foliar application of $\mathrm{GA}_{3}$ at the rate of $30 \mathrm{ppm} \mathrm{ha}^{-1}$ at $20 \& 40 \mathrm{DAS}$. Sulphur in the form of sulphate is involved in various metabolic and enzymatic activities of plants. It is also a constituent of glutathione, a compound supposed to play part in plant respiration and synthesis of oils about $90 \%$ of plant sulphur is present in these amino acids (Tandon and Messick, 2002). The increase in oil content due to sulphur fertilization might be the outcome of better availability of nutrients owing to favourable environment created by sulphur application. As sulphur is an integral part of oil, the increased availability of sulphur might have favourably influenced the synthesis of essential metabolism responsible for higher oil content (Jordon and Reisenaur, 1957).

In conclusion, sulphur application significantly influenced the growth, yield attributing characters and yield. Treatment in which Sulphur was applied at $40 \mathrm{~kg} \mathrm{ha}^{-1}$ along with foliar application of 50 ppm NAA twice at 20 DAS and 40 DAS recorded highest plant height, plant dry matter accumulation, pod yield and oil percentage in sulphur at $50 \mathrm{~kg}$ $\mathrm{ha}^{-1}$ along with foliar application of $\mathrm{GA}_{3} 30$ ppm at $20 \& 40$ DAS.

\section{References}

AICRPG. 2015. Annual Report (Kharif, 2014) All India Coordinated Research Project on Groundnut. ICAR- Directorate of Groundnut Research, Junagadh.

AOAC. 1980. Official methods of analysis, 13th ed. Association of official Oil Analytical chemists. Washington D.C. pp.376-384.

Gopalakrishnan S and Srinivasan P S 1975a. Effect of planofix-an NAA formulation on groundnut. Indian Journal of Agricultural Chemistry 81: 163-166.
Gupta, A.K. and Singh, N.K. 1982. Delineating sulphur deficiency in soils and response studies in principal crop sequences of Semi-Arid Eastern plains of Rajasthan. (In): Proceedings of TSIFAI-IFA Symposium cum- Workshop on "Sulphur in Balanced Fertilization", held during October 4-5, 2006 at New Delhi, India: 91-115.

Jordon, H.V. and Reisenaur, H.M. 1957. Sulphur and soil fertility. (In) Soil Year Book Agriculture, USDA, Washington: 107-111. Kadam, U.A., Pawar, V.S. and Pardeshi, H.P. 2000. Influence of planting layouts, organic manures and levels of sulphur on growth and yield of summer groundnut. Journal of Maharashtra Agriculture Universities 25(2): 211-213.

Jordon, H.V. and Reisenaur, H.M. 1957. Sulphur and soil fertility. (In) Soil Year Book Agriculture, USDA, Washington: 107-111.

Kalaiyarasan, C., Vaiyapuri, V. and Chandrasekharan, M.V.S. 2002. Effect of sulphur sources and levels on the growth and yield of groundnut in red laterite soil. Annals of agricultural Research New Series, 23(4): 618-621.

Patel., G.N., Patel, P., Patel, D.M., Patel, D.K. and Patel, R.M. 2009. Yield attributes, yield, quality and uptake of nutrients by summer groundnut (Arachis hypogaea L.) as influenced by sources and levels of sulphur under varying Irrigation schedule. Journal of oil seed Research. 26(2): 119-122.

Ramnathan, T. 2001. Genetic improvement of groundnut. Associated Publishing Company, New Delhi: 9.

Rao, G.N.S.N.1997. Agrotechniques to improve productivity of rabi irrigated JL 24 groundnut Ph.D Thesis Andhra Pradesh Agricultural University, Hyderabad.

Singh, S., Kumar, Y., Gill, O.P., Singh, S. and 
Kumar, Y. 2008. Growth characteristics of summer groundnut (Arachis hypogaea L.) as influenced by sulphur levels, irrigation schedules and organic manures. Annals of Agriculture Research, 19(2): 135- 139.

Tandon, H.L.S. 1991. Sulphur Research and Agricultural Production in India. 3rd edn. The Sulphur Institute, Washington,
DC, USA: 140+Viii.

Vallippan K, Lakshnanan A $\mathrm{R}$ and Kumaresan. 1985. Effect of different plant growth regulators on the reproductive characters and yield of TMV 7 groundnut. Oilseeds Journal15: 53-56.

\section{How to cite this article:}

Rama Krishna, B. and Rajesh Singh. 2019. Effect of Levels of Sulphur and Plant Growth Regulators on Growth, Yield and Oil percentage of Summer Groundnut (Arachis hypogaea L.). Int.J.Curr.Microbiol.App.Sci. 8(12): 2940-2944. doi: https://doi.org/10.20546/ijcmas.2019.812.341 